classes were performed in total of 18 Periodontology classes. Student evaluation for SGD was taken after the class by anonymous questionnaire. Student activity in SGD was evaluated by resource personnel with recording times and contents of speech in discussion. The knowledge acquisition was analyzed by compering scores in examination regarding SGD theme. Thirty-seven \% of students responded positive for the question of "Did you enjoy SGD?". More self-studied students tended to answer positive for the question of "Did you actively perticipate to SGD?". The results suggested that lecture/tutorial based education had the potential to encourage students' self-study.

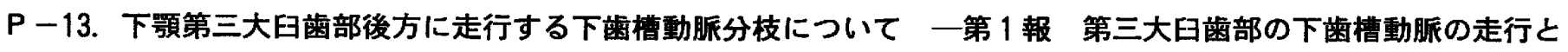
分布について一

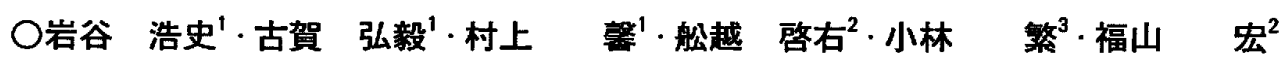

${ }^{1}$ 九霜大·学生会員, ${ }^{2}$ 九霖大·口病, ${ }^{3}$ 九歯大·口解 1

下顎骨内に分布する下雪槽動脈は, 下額孔から 1 本の下歯槽動脈が下靧骨内に進入し, 第三大印歯部からその枝で ある副枝を分枝しながら歯枝，歯肉枝や雪槽枝などに分枝すると言う。しかし，船越の報告 (84 年, 97 年九歯学会) では, 第三大臼霜部で, その歯牙の後方から分枝する動脈性血管が多く分枝することが報告の一部にある.このこと より第三大臼歯部後方の動脈性分布の再検索を行い, 成書の記載の確認を行うべく解析を行った，われわれは，今回 の検索で新知見を得たので報告する。

Distribution mandibular arterial branch behind mandibular third molar. - First report. Mandibular arterial form and distribution around third molar-

Hirofumi Iwatani ${ }^{1}$, Hiroki Koga ${ }^{1}$, Kaoru Murakami ${ }^{1}$, Keisuke Funakoshi ${ }^{2}$, Shigeru Kobayashi ${ }^{3}$ and Hiroshi Fukuyama ${ }^{2}$ ( ${ }^{1}$ Student, ${ }^{2}$ Department of Oral Pathology and ${ }^{3}$ First Department of Oral Anatomy, Kyushu Dental College)

The form of the mandibular arterial branch was investigated in this study. The mixture of bariumsulfate and gelatine was injected into the entrance of mandibular artery synclonizing with blood presssure. After decalcification, it was by Softex imaging and H.E staining.

An arteriole nourishing third molar was found to go out of the entrance of the mandibular artery. It indicates that this arteriole may nourish gingiva behind third molar and also its tooth germ.

\title{
$P-14$. ウサギ葉状乳頭の味蕾の発生学的研究
}

○豊島 邦昭·瀬田 祐司·武田 忍·豊野 孝·原田 英光 九歯大·只解 2

ウサギの葉状乳頭の味蕾は，I，II， III型の 3 種類の細胞型（R. G. Murray）から構成されるが, それぞれの細 胞型の発生, 分化ならびに機能的意義については, まだよく理解されていない，本研究ではウサギを用いて，味蕾の 初期発生から成熟にいたる過程を, 微細構造学的ならびに免疫組織化学的に検索した. 材料には胎生 26 日〜生後 3 日ならびに成体, 老齢化の進んだウサギの葉状乳頭を用いた。胎生 26 日にはすでに葉状乳頭の形成が認められた。 胎生 27 日になると, 神経線維の上皮内侵入に先立って上皮基底部に明調な細胞の出現が観察された. この細胞はサ イトケラチン 20 に免疫陽性で, 細胞質内には而型細胞あるいはメルケル細胞のもに類似した有芯果粒が認められた. 胎生 28 日になると, 多数の神経線維をともなったシュワン細胞様細胞が基底膜を貫き上皮内へと侵入し，II型細胞 の特徵を示す細胞へと分化した. また, I 型細胞は他型の細胞の出現に遅れて周囲のケラチノサイトから分化し, 味 蕾細胞の多元説を支持する結果が得られた。

Embryonic development of taste buds in the rabbit

Kuniaki Toyoshima, Yuji Seta, Shinobu Takeda, Takashi Toyono and Hidemitsu Harada (Second Department of Oral Anatomy, Kyushu Dental College)

Taste buds of mammals are very complex, containing a number of cells of verying morphology and 
function. Although numerous ultrastructural studies have examined taste buds of mammals, controversy still exists regarding the classification of cell types, and of the lineage of taste bud cells. We examined the embryonic development of rabbit taste buds by electron microscopy and immunohistochemistry. At prenatal day 27, relatively larger and lighter cells appeared in the basal position of the epithelium. These cells were immunoreactive for $\mathrm{CK} 20$, and were characterized by the presence of numerous dense-cored granules, resembling those of type III cells of the adult taste bud and of Merkel cells in the epithelium. The emergence of these cells in the epithelium preceded the arrival of nerves. By prenatal day 28, glossopharyngeal nerves entered the epithelium and became associated with type III-like cells. Occasionally, Schwann-like cells, resembling type II cells, accompanied by numerous nerves were found to penetrate via the basal lamina into the epithelium at prenatal day 28. Type I cells differentiated from the surrounding keratinocytes after prenatal day 30. Our results thus indicated that three distinct cell types (type I, I, III) in rabbit taste buds are separate cell lines and never transform into one another.

\section{$P-15$. 食物性状と咀謝粎式}

○平川 輝行·柿山 哲治 九州保健福祉大学・視機能療法学

摄食時の咀嚼運動と食物物性およびテクスチャーとの対応性については種々の報告があるが, それらは単一食物を 個別に摂食させた場合の結果を論じたものがほとんどである. 今回，日常食を自由に摄食させた場合，日常食の食物 性状の相違によって咀㘉様式によ゙のような差異が見られるのか，それらが被験者間で同一傾向を有するのかどうかを 検討した。 口数·箬運動時間·食事時間·咀嘪回数は食事内容によって変化し, 頭頸部の咀嚼に関する種々の筋の活 動量においても同様に変化した。一般的には，パン食は米食に比べ，またコーンスープは他の汁物に比べ，また，う どん食は口数や咀嚼回数が少なくなる傾向があった．頭頸部諸筋の筋電図パターンは食物の口への取り込みや噒み締 め, 與下時に, また食物性状によって特徴を有していた. 食事内容によって被験者間で口数や咀塮回数に異なる変化 が見られることから，摂食行動には生活習慣に裏打ちされた学習が大きく関与していることが考えられる.

\section{Relationship between physical properties of daily meals and masticatory patterns}

Teruyuki Hirakawa and Tetsuji Kakiyama (Department of Orthoptics and Visual Science, Kyushu University of Health and Welfare)

Many researches on relationship between physical properties of foods and masticatory movements deal with it to individual food in experimental condition. This study was done for effects of 10 different types of daily meal on masticatory patterns, such as the numbers of bringing food to mouth and chewing, the duration of taking a daily meal, the total duration of moving chopsticks, and on EMG activities of masticatory and swallowing muscles. Five subjects took part in this study. The numbers of bringing food to mouth and chewing it are not many in the diet with bread or noodle compared with in the diet with rice, and in the soup without ingredients compared with that with it. Integrated value of EMG is directly proportional to the chewing number and the duration of taking a daily meal. It is supposed that the diet with rice elevates the number of chewing a daily meal. 